\title{
THE EUROPEAN COURT OF HUMAN RIGHTS - UNIVERSALIST ASPIRATIONS OF PROTECTION IN THE MIDDLE OF THE EDGE OF OCCUPATION
}

\author{
Susan S MEdwards*
}

\section{INTRODUCTION}

This current commentary considers the case of Al-Saadoon and Mufdhi $v$ the United Kingdom ${ }^{1}$ (a recent decision of the European Court of Human Rights (ECtHR)) and the issues upon which it turns. It raises the question of whether an occupying force has an obligation to protect the human rights of those under occupation. The inherent tensions, conflicts, contradictions, and limits posed in and by such a question are obvious. The occupying force - the UK - in this case constituted itself as part of the Multi-National Force (MNF) and invaded Iraq in 2003. The invasion and occupation was subsequently held to be illegitimate. ${ }^{2}$ The question of whether Iraqi citizens have a right to protection under any International Convention or treaty or any human rights instrument is a question of considerable importance and was the question so

\footnotetext{
*Professor and Dean of Law, University of Buckingham, Barrister, Door Tenant, Clarendon Chambers, 1 Plowden Buildings, Temple, London.

1 Al-Saadoon and Mufdhi $v$ the United Kingdom (Application no. 61498/08) judgement 2 March 2010).

2 The war on Iraq was opposed by many NATO members and the so called "Operation Iraqi Freedom" was not conducted by NATO. The illegitimacy of the action of the US and the UK and the duplicity of its leaders with the fantastic subterfuge and lies that accompanied this particular 'jihad' has been eloquently analysed by Philippe Sands in his book Lawless World (Penguin: London 2006). See also Kofi Annan, who in September 2004, publicly stated that the war on Iraq was illegal. In November 2004, the senior policy advisor to the Prime Minister acknowledged: "we allowed our judgement of the dire consequences of inaction to override our judgement of the even more dire consequences of parting from the rule of law” see S Wall, The Independent November $9^{\text {th }} 2004$ p 31. See also Elizabeth Wilmhurst's resignation on $18^{\text {th }}$ March: "I regret I cannot agree that it is lawful to use force....".
} 
considered, in the case of $\mathrm{Al}$-Saadoon and Mufdhi, in the case of $\mathrm{Al-Skeini}{ }^{3}$ and whether British forces were so protected was considered in $R$ (Smith) $v$ Secretary of State for Defence, ${ }^{4}$ to which I shall refer later.

Viewed by Western democratic governments as repugnant (a view enshrined as a principle in the laws that bind them) and outlawed by Art 1 Protocol 13 to the European Convention on Human Rights (ECHR), the death penalty is the very starting point and paramount consideration for the European Court of Human Rights (ECtHR) in the case of Al-Saadoon and $M u f d h i{ }^{5}$ This and other rights, including the right to be free from inhuman and degrading treatment (Article 3), and the right to a fair trial (Article 6), are revered, protected, and regarded as emblematic of the rule of law which is proclaimed and cherished by Western democracies. The foreign policy of Western democracies, especially its incursions and foraging into other territories, is presented by Western governments through the lens of the will to liberate, to civilise and to deliver the rule of law. The human rights protected by the ECHR enshrine an inalienable code of conduct which the UK government wishes to export to non-democratic societies and to the developing world. It is this very objective and humanitarian purpose - the export of human rights - which the UK government has proclaimed provides one of the key justifications for UK foreign policy in the invasion of Iraq. ${ }^{6}$ Indeed, using human rights to sell war $^{7}$ perhaps characterises the position of the UK and the US with regard to the invasion of Iraq. It is perhaps worth noting, at this point, the words of George Orwell:

"In our time, political speech and writing are largely the defence of the indefensible. Things like the continuance of British rule in India, the Russian purges and deportations, the dropping of atom bombs on Japan, can indeed be defended, but only by arguments which are too brutal for most people to face, and which do not square with the professed aims of political parties. Thus political language has to consist largely of euphemism, question-begging and sheer cloudy vagueness... When there is a gap between one's real and one's

\footnotetext{
${ }^{3} R$ (on the application of Al-Skeini and others) $v$ Secretary of State for Defence [2007] UKHL 26, [2007] 3 All ER 685.

${ }^{4} R$ (Smith) v Secretary of State for Defence Jun 10[2010] UKSC 29.

${ }^{5}$ See above n 3 para 115.

${ }^{6}$ N Chomsky Power and Terror (London: Palgrave Macmillan, 2003) p 37: "Every time Blair or Bush or Clinton or Madeleine Albright or someone calls for war on Iraq, they always say it the same way. They say, [T]his is the worst monster in history. How can we allow him to exist? He even committed the ultimate crime: he used gas "against his own people." How can such a person exist?"

${ }^{7}$ J Bricmont Humanitarian Imperialism: Using Human Rights to Sell War (New York Monthly Review Press, 2007).
} 
declared aims, one turns as it were instinctively to log words and exhausted idioms...Political language - and with variations this is true of all political parties, from Conservatives to Anarchists - is designed to make lies sound truthful and murder respectable..."”

It is also significant that the war on Iraq was presented by the UK and the USA as a quest and mission to assist the national liberation struggle. ${ }^{9}$ At the same time as these hallowed reasons for the invasion of Iraq, Stephen Poole in his critique reveals how language is instrumental in masking the truth. ${ }^{10}$ Whilst Philippe Sands QC unmasks the reality. ${ }^{11}$

The urgent question which this current commentary considers is whether Iraqi citizens, who are alleged to have been involved in the deaths of two British soldiers during the occupation of Iraq by British and American forces (the MNF) $)^{12}$ - the Al-Saadoon case - are entitled to protection and basic human rights, inter alia, the rights enshrined in the ECHR. This is considered alongside two further questions, the first is whether Iraqi civilians killed by the British forces are entitled to ECHR protection - the Al-Skeini case, and the second is whether British soldiers on active service outside the UK are entitled to the protection of the ECHR - the Smith case. Such a question is considered within the existing framework of legal principles of international law, and international criminal justice but it is as much a moral question as it is a legal one.

${ }^{8}$ G Orwell "Politics and the English Language" George Orwell: Essays (London: Penguin, 2000) pp 348-360. See also S Poole Unspeak (London Little Brown, 2006) p 5 .

9 Bush euphemistically called the invasion of Iraq “Operation Iraqi Freedom”. See also, G Stedman Jones "The History of US Imperialism” in R Blackburn (ed) Ideology in Social Science (London Fontana, 1976): "Many illusions about the historical development of the United States derive from a failure to appreciate its underlying continuity. The non-territorial nature of US imperialism during some important periods obscured this fact and allowed many historians to represent the United States as a champion of national liberation.” p 207.

${ }^{10}$ See Poole above $n 8$.

${ }^{11}$ See Sands above $\mathrm{n} 2$ especially Chapter 8 entitled "Kicking Ass in Iraq."

12 The Multi-National Force - Iraq (MNF-I) was led by the US, it was a military command which claimed to be responsible for "Operation Iraqi Freedom". The objectives, were expressed in June 2004 in an annex to UNSCR 1546, in which U.S. Secretary of State Powell in a letter to the UN Security Council, stated, "The MNF under unified command is prepared to continue to contribute to the maintenance of security in Iraq, including by preventing and deterring terrorism and protecting the territory of Iraq. The goal of the MNF will be to help the Iraqi people to complete the political transition and will permit the United Nations and the international community to work to facilitate Iraq's reconstruction.” 


\section{THE INVASION OF IRAQ}

“On 20 March 2003 a coalition of armed forces, the 'MNF', led by the United States of America with a large force from the United Kingdom and smaller contingents from Australia and Poland, commenced the invasion of Iraq. ${ }^{13}$...The United States and the United Kingdom thereafter became occupying powers within the meaning of Section III of the Hague Regulations on the Laws and Customs of War on Land, 1949 and the Fourth Geneva Convention on the Protection of Civilians in Time of War, 1949." 14

The British government's proclaimed reasons for the invasion of Iraq were that (1) Saddam Hussein was developing "weapons of mass destruction", (2) there was a need both to promote democracy in Iraq and (3) to challenge Saddam Hussein's human rights record. In claiming to bring human rights to Iraq, the occupiers, inevitably, set themselves up as champions of human rights protection with the consequence that, because of their own high grounded claims and promises, their human rights example in Iraq was up for scrutiny and examination, both legally and morally. This invasion which some would argue is a demonstration of human rights imperialism is an aspect to which I shall return later.

\section{The Deaths of British soldiers and the Iraqi suspects}

On, or about, March $23^{\text {rd }} 2003$, Staff Sergeant Simon Cullingworth and Sapper Luke Allsopp, two British soldiers serving in Iraq, were abducted and killed by Iraqi Militia forces. Faisal Attiyah Nassar Khalaf Al-Saadoon and Khalef Hussain Mufdhi were suspected of involvement in the killings. From 2003 to December 2008 Al-Saadoon and Mufdhi and former senior officials of the Ba'ath party were detained pending investigation and trial in a British run detention facility - the "Divisional Temporary Detention Facility" - and from April 20 th 2008 until December 2008 they were detained in the "Divisional Internment Facility" again, under British detention. Following the Iraqi Council of Ministers' Resolution (50/2008 of 23 December 2008), all occupying forces were to withdraw from Iraq no later than July $31^{\text {st }} 2009$. From 2003 to May $21^{\text {st }} 2006$ the British authorities classified Al-Saadoon and Mufdhi as "security internees" on the basis of resolution 1546, and after May $21^{\text {st }} 2006$ and until December $31^{\text {st }} 2008$, reclassified them as "criminal

13 Fourth Section Case of Al-Saadoon and Mufdhi $v$ The United Kingdom (Application no. 61498/08 Judgement 2 March 2010. para [10].

${ }^{14}$ Fourth Section Case of Al-Saadoon and Mufdhi $v$ The United Kingdom (Application no. 61498/08 Judgement 2 March 2010. para [11]. 
detainees”. On December 27th, 2007, the Iraqi authorities (the Iraq High Tribunal (IHT) $)^{15}$ formally requested the British forces to transfer them into its custody and from this moment they were detained by British forces at the 'behest' of the Iraqi government.

The applicants, did not wish for this transfer from British into Iraqi custody because, since Iraq had reintroduced the death penalty in 2004, they feared they would be executed following an order from an Iraqi court, if they were found guilty of any involvement with the killings. Represented by Public Interest Lawyers, ${ }^{16}$ Al-Saadoon and Mufdhi on June $12^{\text {th }} 2008$, issued judicial review proceedings in the UK, challenging the legality of the proposed transfer.

Their application raised important legal matters of UK jurisdiction in Iraq as to (1) whether the UK, as one of the occupying forces, had an obligation and duty to ensure that Iraqi citizens were protected by law, and (2) whether the law of the ECHR extended to them. Their application for judicial review was refused. They appealed this decision to the Court of Appeal on $29^{\text {th }}$, $30^{\text {th }}$ December 2008, and January $21^{\text {st }}$ 2009. The Court of Appeal was required to consider whether the two men, whose status was first as persons arrested by British forces in Iraq having been suspected originally of orchestrating violence against the coalition forces and detained as security internees before being reclassified as criminal detainees and then placed under the authority of an Iraqi court, were persons who were eligible for the protection under the ECHR. The Court of Appeal concluded that the UK government were under no such obligation to afford the men protection under the ECHR since they had been transferred into the control of the Iraq authorities. Following this decision, the British government defied the Strasbourg injunction issued on December $30^{\text {th }}$ 2008, which prohibited the transfer of the two men until further notice, under Rule 39 of the Rules of Court, ${ }^{17}$ and in breach of this injunction transferred the applicants into the control of the Iraqi government. ${ }^{18}$

${ }^{15}$ In 2003, a special court-the Iraq Domestic Tribunal-was established in Iraq to hear crimes committed by the previous regime and was created by a national statute from the Interim Governing Council. In 2005, it was ratified and renamed as the Iraq High Tribunal by the Iraqi Transitional National Assembly. Its statute provides jurisdiction for certain international crimes committed by Iraqi's during the Ba'athist regime July 1968 to May 2003.

${ }^{16} \mathrm{PIL}$ - "Public Interest Lawyers is a leading public law firm specialising in domestic and international human rights and environmental and planning law. In recent years we have brought on behalf of our clients many of the seminal judicial review cases in these areas."

http://www.publicinterestlawyers.co.uk/cases/cases.php?id=126

${ }^{17}$ Rule 39 (Interim measures) "1. The Chamber or, where appropriate, its President may, at the request of a party or of any other person concerned, or of its own motion, indicate to the parties any interim measure which it considers should be adopted in the 
Their lawyers lodged an appeal from the decision of the Court of Appeal to the ECtHR challenging the legality of the transfer from British into Iraqi custody and the resulting abrogation of Convention rights with regard to their suffering as a result of their uncertain status prior to trial and their fear of execution which was a real possibility, if not a certainty, should they be found guilty at trial or on appeal. On May $26^{\text {th }} 2009$, Al-Saadoon and Mufdhi faced trial in an Iraqi court (IHT) ${ }^{19}$ for their alleged involvement in the killing of the two British soldiers. Prosecution witnesses recanted their original statements, and in September of that year ${ }^{20}$ charges against them were dismissed on grounds of insufficient evidence. The Court said however that they had not been found innocent and could be retried within 12 months should evidence be found against them. The prosecutors appealed and the two men were then further remanded in custody pending an appeal hearing.

In May 2010, the ECtHR, in reversing the decision of the Court of Appeal, found that the applicants did indeed fall within the jurisdiction of the ECHR because they were in the custody of the British forces at the relevant time - the time of their arrest: and once arrested they were then entitled to protection throughout the duration of the judicial process, and were "at real risk of being subjected to an unfair trial followed by execution by hanging"

interests of the parties or of the proper conduct of the proceedings before it. 2. Notice of these measures shall be given to the Committee of Ministers. 3. The Chamber may request information from the parties on any matter connected with the implementation of any interim measure it has indicated". See Court Européenne des droits de l'homme. European Court of Human Rights, Rules of Court (July 2009) Registry of the Court, Strasbourg.

${ }^{18}$ Public Interest lawyer, Phil Shiner said in response to the ECtHR ruling in March 2010, with regard to the UK's breach of the original injunction of the ECtHR not to transfer the two men, "It is a national disgrace that our government, in breach of an injunction by the European court, was prepared to hand our clients to the Iraqi authorities when they knew full well that they faced the real risk of being executed by hanging," (Morning Star March $3^{\text {rd }}$ 2010). It is to be noted also that this is the first time the UK Government has acted in breach of an injunction issued by the European Court. Phil Shiner went on, "It beggars belief that a Labour government should act in such flagrant disregard for the rule of law and to have put two fingers up to the European Court in the process." He went even further and accused the MoD of a "vindictive" and "flagrant disregard for the rule of law", arguing that this case is "about fundamental principles - the right to life and the prohibition of torture."

${ }^{19}$ UPI NewsTrack Top News May $26^{\text {th }} 2009$.

${ }^{20}$ Defence minister, Bob Ainsworth took the view that the Government had taken the right course of action and said, "We had been put in an extraordinary position with this injunction. They were effectively asking us to do something illegal. We have no legal powers to hold these individuals. It is the right decision that they face trial in Iraq where these crimes were committed." (The Independent January $1^{\text {st }} 2009$ ). 
and had been "subjected to mental suffering caused by the fear of execution amounting to inhuman treatment" whilst in detention.

Let us consider in some detail the jurisprudence and reasoning of the British courts and the jurisprudence and reasoning of the ECtHR on these overarching questions.

\section{BRITISH COURTS AND A NARROW VISION OF JURISDICTION}

\section{The Divisional Court}

The case of Al-Saadoon and Mufdhi first came before a British court with regard to challenging, via a judicial review, the decision to transfer them into Iraqi control on June $12^{\text {th }} 2008$. The Divisional Court (Richards LJ and Silber $\mathrm{J}$ ), in giving judgement on December $19^{\text {th }} 2008,{ }^{21}$ concluded that their proposed transfer into Iraqi control was indeed lawful. The applicants claimed that a transfer into Iraqi custody would place them, if convicted, as I have already pointed out, under risk of execution by hanging, and that this would violate not only their rights under the ECHR but also would be contrary to the free-standing principles of public international law condemning the death penalty. On the jurisdictional question, the Divisional Court concluded that there was no real risk of them being treated in any way contrary to international norms and that therefore, there was no justification for the UK not to transfer them. In fact, they went further and concluded that international law positively required them to transfer the applicants into the custody of the Iraqi court. In arriving at this conclusion they applied the test in $R(B) v$ Secretary of State for Foreign and Commonwealth Affairs which held: "that the authorities of the receiving state can require surrender of a fugitive in respect of whom they wish to exercise the authority that arises from territorial jurisdiction." ${ }^{22}$ They also considered Munaf $v$ Geren, ${ }^{23}$ a decision of the US Supreme Court, which raised a similar question in respect of US jurisdiction. In adopting a restrictive and archaic view of jurisdiction, the Supreme Court said:

"The habeas petitioners do not dispute that they voluntarily traveled to Iraq, that they remain detained within the sovereign territory of Iraq

\footnotetext{
${ }^{21}$ [2008] EWHC 3098 (Admin), [2008] All ER (D) 246 (Dec).

22 [2008] EWHC 3098 (Admin), [2008] All ER (D) 246 (Dec) para [69].

${ }^{23}$ [2008] EWHC 3098 (Admin), [2008] All ER (D) 246 (Dec) para [23]. See also Supreme Court of the United States Syllabus Munaf et al v Geren, Secretary of the Army, et al. Certiorari to the United States Court of Appeals for the District of Columbia Circuit No 06-1666. Argued March $25^{\text {th }} 2008$ - Decided June $12^{\text {th }} 2008^{*}$
} 
today, or that they are alleged to have committed serious crimes in Iraq. Indeed, Omar and Munaf both concede that, if they were not in MNF-I custody, Iraq would be free to arrest and prosecute them under Iraqi law. Further, Munaf is the subject of ongoing Iraqi criminal proceedings and Omar would be but for the present injunction. Given these facts, Iraq has a sovereign right to prosecute them for crimes committed on its soil, even if its criminal process does not come with all the rights guaranteed by the Constitution, see Neely v. Henkel, 180 U. S. 109, 123. As Chief Justice Marshall explained nearly two centuries ago, "[t]he jurisdiction of the nation within its own territory is necessarily exclusive and absolute." Schooner Exchange $v$. McFaddon, 7 Cranch 116, 136. This Court has twice applied that principle in rejecting claims that the Constitution precludes the Executive from transferring a prisoner to a foreign country for prosecution in an allegedly unconstitutional trial. Wilson, supra, at 529-530; Neely, supra, at 112-113, 122.”

On the fair trial point, the Divisional Court concluded that there was no risk that they would not receive a fair trial (Article 6 ECHR) and said, "the evidence before us falls a long way short of establishing substantial grounds for believing there to be a real risk that a trial of the claimants would involve a "flagrant breach" of the principles guaranteed by article 6 . Thus, even if the Convention were to apply in the normal way, we would reject the claim that transfer of the claimants into the custody of the IHT would be contrary to article 6." ${ }^{24}$ (I will return to discuss the threshold of "flagrant breach" later). In concluding that the proposed transfer would be lawful the Court did say:

"Whilst we have been led to that conclusion by our analysis of the legal principles and the factual evidence, we are seriously troubled by the result, since on our assessment the claimants, if transferred, will face a real risk of the death penalty in the event that they are convicted by the Iraqi court. In all normal circumstances the Convention (as well as the Extradition Act 2003 in extradition cases) would operate to prevent such a result. It arises here only because of the highly exceptional circumstances of the case and the application to them of the principles in $R(B) v$. Secretary of State for Foreign and

\footnotetext{
${ }^{24}$ [2008] EWHC 3098 (Admin), [2008] All ER (D) 246 (Dec). Cited in the EHCR judgement Al-Saadoon and another $v$ United Kingdom (App No 61498/08) [2010] at para [59].
} 
Commonwealth Affairs, as we have understood the judgement of the Court of Appeal in that case....” 25

The Divisional Court, in their reasoning however, drew a distinction between the case of $\mathrm{Al}$-Saadoon and $\mathrm{Al}$-Skeini ${ }^{26}$ and said that in the Al-Skeini case the ECHR jurisdiction applied because no sovereign government existed in Iraq at the time of the killing of Baha Mousa by British forces, whereas in the case of Al-Saadoon there was indeed a government in office in 2008, the time deemed by the court to be the relevant time. Let us then turn to the facts of $\mathrm{Al}$-Skeini ${ }^{27}$ which is a test case brought by the families of six victims, from a very much larger number of claims. The question of the ambit of ECHR protection was considered by the House of Lords, (Lord Bingham of Cornhill, Lord Rodger of Earlsferry, Baroness Hale of Richmond, Lord Carswell and Lord Brown of Eaton-under-Heywood). In this case, five Iraqi citizens were shot by British troops in the streets or in their homes in Basra, which the UK occupied. Hazim Jum'aa Gatteh Al-Skeini was attending a funeral and was shot dead by a British soldier on August $4^{\text {th }}$ 2003. Hannan Mahaibas Saeed Shmailawi was with her husband and family at the Institute of Education in Basra when the building was fired on by British forces. She was shot dead. Muhammad Abdul Ridha Salim was at his brother-in-law's house when a soldier fired a rifle into his stomach causing his death. Waleed Fayayi Muzban was driving home from work when British soldiers fired at him from behind causing his death. Raid Hadi Sabir Al Musawia, in his role as a policemen, was taking a box of "suggestions and complaints" to a judge's house, when he was shot dead by a British patrol. The House of Lords considered all these five victims to be "outside the jurisdiction" for the purposes of Article 1 of the Convention confirming what had previously been

25 [2008] All ER (D) 246 (Dec)*R (on the application of Al-Saadoon and another) $v$ Secretary of State for Defence [2008] EWHC 3098 (Admin) Para [204]. Cited in the EHCR judgement, ibid, at Para [62].

${ }^{26} R$ (on the application of Al-Skeini and others) $v$ Secretary of State for Defence [2007] UKHL 26 [2007] 3 All ER 685.

27 [2008] 1 AC 153 (per Lord Bingham of Cornhill) “My Lords, ... These proceedings arise from the deaths of six Iraqi civilians, and the brutal maltreatment of one of them causing his death, in Basra. Each of the deceased was killed (or, in one case, is said to have been killed) and the maltreatment was inflicted by a member or members of the British armed forces. In each case a close relative of the deceased has applied in the High Court in London for an order of judicial review against the Secretary of State for Defence, seeking to challenge his refusal (by a letter of 26 March 2004) to order an independent enquiry into the circumstances of this maltreatment and these deaths, and his rejection of liability to afford the claimants redress for causing them. These six cases have been selected as test cases from a much larger number of claims in order, at this stage, to resolve certain important and far-reaching issues of legal principle.” 
held by the Divisional Court and also confirmed on appeal. A sixth person, Baha Mousa, who was captured and later tortured and killed in a UK military detention facility was however considered to be "within the jurisdiction" for the purposes of Article 1, since he had been killed by British troops when he was held as a prisoner in a British military detention unit. This was also the view of the Divisional Court and the Court of Appeal. Lord Brown of Eatonunder-Heywood, in the House of Lords said:

“... I for my part would recognise the UK's jurisdiction over $\mathrm{Mr}$ Mousa only on the narrow basis found established by the Divisional Court, essentially by analogy with the extraterritorial exception made for embassies (an analogy recognised too in Hess $v$ United Kingdom (1975) 2 DR 72, a commission decision in the context of a foreign prison which had itself referred to the embassy $X v$ Federal Republic of Germany).,28

Although, Lord Bingham in the House of Lords said:

"I would accordingly hold that the 1998 Act has no extra-territorial application. A claim under the Act will not lie against the Secretary of State based on acts or omissions of British forces outside the United Kingdom. This does not mean that members of the British armed forces serving abroad are free to murder, rape and pillage with impunity. They are triable and punishable for any crimes they commit under the three service discipline Acts already mentioned..."29

The interpretation of "territory" and the obligations of the occupying force in Al-Skeini, was of such overriding importance as a matter of principle that InterRights submitted a third party intervention jointly with the Bar Human Rights Committee, the European Human Rights Advocacy Centre, Human Rights Watch, the International Federation for Human Rights, the Law Society, and Liberty. Their intervention focused on the issue of the extraterritorial application of human rights law, especially the application of the European Convention on Human Rights. The interveners argued that a narrow interpretation of "jurisdiction" would create double standards and observed:

“During the 1930's and 40's appalling human rights abuses were carried out across Europe by military forces within occupied

\footnotetext{
${ }^{28}$ Ibid at para 132.

${ }^{29}$ Ibid Lord Bingham of Cornhill para 26 at 704.
} 
territories. It is inconceivable in this context that the drafters of the Convention, amongst whom were such notables as Pierre-Henri Teitgen who had been captured and tortured by the forces of the belligerent occupier of France, should have considered that the prospective responsibilities of states under the Convention should be confined to the violations of human rights perpetrated only within their own territories. Such an approach would have meant that states could be held accountable for Buchenwald, but not for Auschwitz, and not for the extraterritorial reprisals and atrocities carried out by the occupying forces that took place in eg Poland, Ukraine, Czechoslovakia, Greece, the Netherlands or France.”30

Having considered the Al-Skeini judgement, the Divisional Court in AlSaadoon concluded that a decision, therefore, not to meet the request of the Iraqi government, and to defy the request to transfer the two men into Iraqi custody could be regarded as an interference with Iraq's sovereign government. ${ }^{31}$

In considering the question of whether a situation falls within the jurisdiction of a state for the purposes of Article $1,^{32}$ the House of Lords in $\mathrm{Al}$ Skeini held that the national court should be guided by the decision of the Strasbourg court in Bankovic v Belgium. ${ }^{33}$ In that case, which considered the territoriality of NATO forces in Yugoslavia, the court held that only in exceptional cases could acts of the contracting states outside their territories constitute an exercise of jurisdiction by them within the meaning of Article 1 of the Convention. ${ }^{34}$ Although Bankovic does not set out with any clarity what an exception might be, the Divisional Court nevertheless followed this approach and deemed $\mathrm{Al}$-Saadoon not to be sufficient of an exception. ${ }^{35}$ Although it is to be noted that the Bankovic decision has been held in some circles to be flawed. ${ }^{36}$ In Al-Skeini (with regard to the deceased victim Baha Mousa) the House of Lords held that Article 6 of the ECHR applies to a

\footnotetext{
${ }^{30}$ InterRights submission in Al-Skeini see http://www.interights.org/al-skeini

${ }^{31}$ Ibid, [2008] EWHC 3098 (Admin), [2008] All ER (D) 246 (Dec) at para [67].

32 Article 1 "The High Contracting Parties shall secure to everyone within their jurisdiction the rights and freedoms defined in Section I of this Convention” as per ECHR.

33 Bankovic v Belgium (Application 52207/99) (2001) 11 BHRC 435.

34 See for a critique of the restrictive interpretation of territory in this case $\mathrm{K}$ Altiparmak “Bankovic: An Obstacle to the Application of the European Convention on Human Rights in Iraq"? Journal of Conflict and Security Law 20049 (213).

${ }^{35}$ See the relevant case law on this point, Loizidou $v$ Turkey (preliminary objections) (1995) 20 EHRR 99, Soering v UK [1989] ECHR 14038/88.

${ }^{36}$ See Altiparmak above n 33.
} 
public authority acting outside the territory of the United Kingdom but within the jurisdiction of the United Kingdom, within the meaning of article 1 of the Convention. Article 1 provides that contracting states shall secure to everyone "within their jurisdiction" the rights and freedoms defined in the Convention. The Divisional Court in Al-Saadoon relied on the finding of the Divisional Court in Al-Skeini which was also approved by the House of Lords in $\mathrm{Al}$ Skeini:

"It is not at all straining the examples of extraterritorial jurisdiction discussed in the jurisprudence considered above to hold that a British military prison, operating in Iraq with the consent of the Iraqi sovereign authorities, and containing arrested suspects, falls within even a narrowly limited exception exemplified by embassies, consulates, vessels and aircraft, and in Hess $v$ United Kingdom 2 DR 72, a prison" and that "[w]e can see no reason in international law considerations, nor in principle, why in such circumstances the United Kingdom should not be answerable to a complaint, otherwise admissible, brought under articles 2 and/or 3 of the Convention." ${ }^{37}$

\section{Court of Appeal - jurisdiction in Basra? "manifestly absurd"}

The applicants, Al-Saadoon and Mufdhi, then appealed the decision of the Divisional Court, to uphold the ruling of the IHT, to the Court of Appeal. ${ }^{38}$ Before Waller, Laws and Jacob LJJ, their lawyers contended that if the two men were transferred into Iraqi custody there were substantial grounds for believing that if they were convicted, they would face a real risk of execution by hanging. ${ }^{39}$ In reply to the submission, advanced on their behalf, that execution by hanging was generally condemned by the law of nations, the Court of Appeal said that: "No freestanding rule of regional customary international law of non-refoulement by European states to third countries where the death penalty might be carried out existed." 40

On the territoriality question, the applicants argued that since they had been detained by the British forces in Iraq they fell within the jurisdiction of the United Kingdom for the purposes of the Convention. They argued that an international law question arose with regard to a principle of regional

\footnotetext{
${ }^{37}$ [2008] All ER (D) 246 (Dec)*R (on the application of Al-Saadoon and another) $v$ Secretary of State for Defence [2008] EWHC 3098 (Admin) at Para [40] citing the Divisional Court in Al-Skeini with reference to Baha Mousa [2007] QB 140, para 287. ${ }^{38} R$ (on the application of Al-Saadoon and another) $v$ Secretary of State for Defence [2009] EWCA Civ 7.

${ }^{39}$ See ibid [22], [73], [74] above.

${ }^{40}$ Ibid para [3], [63].
} 
customary law, with regard to whether hanging was regarded as a crime against humanity and/or inhuman or degrading treatment. On the jurisdictional question, the Court of Appeal upheld the decision of the Divisional Court, and, although using rather more elaborate and diffuse language, said that whilst having no "sharp edge" jurisdiction was a concept and reality derived from "strategic rather than lexical thinking." ${ }^{41}$ The Court of Appeal said that the scope of the ECHR was "the 'espace juridique' of the states parties" ${ }^{42}$ thereby endorsing the so-called 'espace juridique' principle. ${ }^{43}$ In considering, in the words of Laws LJ, "whether the ECHR writ runs, so to speak, to the British base in Basra," ${ }^{44}$ the Court of Appeal concluded that it did not! In essence, what this means is that the construct of jurisdiction relies on a conservative model of territory conceived as an organic enterprise, and in this regard the Court of Appeal appealed to an understanding of "natural setting." Laws LJ went further and asserted that the argument that the ECHR had any ambit in Basra was "manifestly absurd". As he pointed out:

"The essentially regional nature of the Convention is relevant to the way that the court operates. It has judges elected from all the contracting states, not from anywhere else. The judges purport to interpret and apply the various rights in the Convention in accordance with what they conceive to be developments in prevailing attitudes in the contracting states. This is obvious from the court's jurisprudence on such matters as the death penalty, sex discrimination, homosexuality and transsexuals. The result is a body of law which may reflect the values of the contracting states, but which most certainly does not reflect those in many other parts of the world. So the idea that the United Kingdom was obliged to secure observance of all the rights and freedoms as interpreted by the European Court in the utterly different society of southern Iraq is manifestly absurd." 45

The Court of Appeal followed established law where standards and principles have already been diluted in respect of some applicants and not

\footnotetext{
${ }^{41}$ Ibid para [37].

42 Ibid para [39].

43 See R Wilde, “The 'legal space' or 'espace juridique’ of the European Convention on Human Rights: is it relevant to extraterritorial state action”? European Human Rights Law Review (2005) 10, 2 115-124. See also "The British Military in Iraq applicability of the espace juridique doctrine" [2005] PL 448, S Miller "Revisiting Extraterritorial Jurisdiction: A Territorial Justification for Extraterritorial...” European Journal of International Law (2009) 20 1223-1246.

${ }^{44}$ Ibid para [15].

${ }^{45}$ Ibid para [78].
} 
others. For example, on the question of "real risk" of hanging, the Court of Appeal queried whether "real risk" was actually the test applicable in "so called foreign cases," accepting that in such cases the extent of the risk had to be not merely "real" but "flagrant," 46 albeit concluding however, that the standard of proof is that of real risk. ${ }^{47}$ Such a distinction between the extent of the risk required and its threshold of "flagrant", with a standard of proof at the threshold of "real risk" is difficult if not impossible to articulate, comprehend, or divine, creating a parallel standard for human rights in so called foreign cases. The approach of the British courts to the jurisdictional question, in my view, can only be said to be "making the world a safer place for hypocrisy." 48

Immediately following the decision of the Court of Appeal, the European Court issued an injunction to prohibit the transfer, notwithstanding, the two men were handed over to the Iraqi authorities. Their legal team asserted with some dismay, "They were transferred despite the court injunction, the lack of evidence against them, the unpredictable and highly political nature of the IHT proceedings and the very real risk that a death sentence would be imposed." 49

\section{Human Rights imperialism}

Laws LJ, in invoking a novel concept, went on to say that interference of the kind desired by the applicants would put the court in a position which "would run the risk not only of colliding with the jurisdiction of other human

${ }^{46}$ It is to be observed that protection and justice as applied to foreign nationals, 'foreign cases', so called, and in this case to occupied peoples, demonstrates two tiers of human rights as practiced. For example, in considering a decision to deport from the UK, the UK courts must consider whether any person deported will face the risk of torture or inhuman treatment, or an unfair trial. The acid test with regard to their rights under article 3 of the European Convention on Human Rights is that deportation will expose them to a "real risk" of torture or inhuman treatment. With regard to fair trial under article 6, the litmus test is that there is a real possibility that trial in another country will be a "flagrant breach" or a real risk of a "total denial of the right to a fair trial.” These higher bars of real risk of torture (article 3) and total denial of fair trial (article 6) were upheld in the House of Lords decision in the case of Mr. Othman (Abu Qatada, February 18 2009 RB (Algeria) v Secretary of State for the Home Department; U (Algeria) v Secretary of State for the Home Department; Othman v Secretary of State for the Home Department [2009] UKHL 10, [2009] 4 All ER 1045).

${ }^{47}$ Ibid para [16].

${ }^{48}$ T Wolfe Look Homeward Angel 1920 (London: Penguin Edition 1990).

${ }^{49}$ http://www.publicinterestlawyers.co.uk/cases/cases.php?id=126 accessed July $2^{\text {nd }}$ 2010. 
rights bodies but of being accused of human rights imperialism.” ${ }^{50}$ With the greatest respect, I cannot agree with Laws LJ. Human rights organisations widely and broadly were concerned that the men would face the death penalty and given the fact of their broad and wide involvement and concern rather than collision, they appeared united. Indeed, the many human rights groups that joined the case as interveners is a testament to the very broad support these men and/or the principles involved in their case secured.

Of course there is a problem of human rights imperialism, but it is not an issue in my view with respect to the right to protection of Al-Saadoon and Mufdhi from the death penalty. Human rights imperialism, certainly characterises the invasion of Iraq by foreign powers. Human rights imperialism is evident for example, in the way in which claims to universalist principles are hollow since the human rights instruments, are drafted largely by the West, and therefore are characterised by 'ethnocentricism' or 'anthropocentricism' on the one hand and, by 'orientalism' or 'cultural imperialism, ${ }^{51}$ on the other. Perhaps this problem and limitation is best articulated by Sardar, who writes:

\begin{abstract}
“There is, ...nothing 'natural' about human rights ... just as democracy is a cynical ploy for post modernising the non-west, human rights too have become an instrument for promoting the western agenda.... The western liberal notion of human rights, which is the basis for the UN Declaration of Human Rights, reduces the issue of the rights of human beings simply to preserving the civil liberties of individuals and provides a moral high ground for these rights to be imposed, by coercion if necessary, on all nonwestern and by definition illiberal, people." ${ }^{52}$
\end{abstract}

Ethnocentricism or anthropocentricism characterises the way in which human rights reflect Western values ${ }^{53}$ (and the way in which the West becomes the template for the world. Said in Culture and Imperialism, ${ }^{54}$ argues that the British, French and American imperial experience had a unique cultural centrality creating what he calls a "totalizing discourse." ${ }^{55}$ It is this "totalising discourse" which is demonstrated in the invasion and

\footnotetext{
${ }^{50}$ Ibid para [78]

${ }^{51}$ D L Donoho, "Relativism Versus Universalism in Human Rights: The Search for Meaningful Standards” 27 Stan.J.International L. 345,353 (1991).

52 Z Sadar Postmodernism and the Other (London: Pluto, 1998) p 67.

53 J A M Copbbah "African Values and the Human Rights Debate: An African Perspective” 9 Human Rights Quarterley 309 (1987).

${ }^{54}$ E Said Culture and Imperialism (London: Vintage, 1994) p xxv.

${ }^{55}$ Ibid xxvii.
} 
occupation of Iraq. Such "civilising” projects resonate of the crusaders jihad against Saledin. ${ }^{56}$ Samir Amin calls this contemporary "project" an expression of "eurocentricism." 57 These narratives masquerade as high theory and define the constructs of human rights, which, as Pollis and Schwab write:

"(is) a twentieth-century concept ... embedded in the United Nations (which) can be traced to the particular experiences of England, France and the United States.... Thus to argue that human rights has a standing which is universal in character is to contradict historical reality. What ought to be admitted by those who argue universality is that human rights as a Western concept based on natural right should become the standard upon which all nations ought to agree, recognising, however, that this is only our particular value system." 58

But it is not, in my view eurocentric or ethnocentric to resist the imposition of the death penalty wherever it lurks in the world.

\section{EUROPEAN COURT OF HUMAN RIGHTS - THE WILL TO DO JUSTICE}

On December $22^{\text {nd }}$ 2008, an application (no. 61498/08), against the United Kingdom of Great Britain and Northern Ireland was made which alleged that the detention and transfer of Al-Saadoon and Mufdhi gave rise to violations of their rights under articles 2, 3, 6, 13 and 34 of the Convention and Article 1 of Protocol No. 13. On December $30^{\text {th }}$ 2008, the Acting President of the Section granted the applicants request, under Rule 39 of the Rules of Court, for an interim measure. In spite of this, on December $31^{\text {st }}$ the two men were transferred into Iraqi custody. On February $17^{\text {th }} 2009$, their case was given priority under Rule $41 .^{59}$ On March $20^{\text {th }} 2009$ the Equality and Human Rights Commission was granted leave to intervene as a third party. ${ }^{60}$ Also granted leave to intervene on March $25^{\text {th }}$ 2009, were the Bar Human Rights Committee of England and Wales, British Irish Rights Watch, the European

\footnotetext{
${ }^{56}$ T Ali The Book of Saledin Islam Quintet 2 (London: Verso, 1999).

${ }^{57}$ S Amin Eurocentricism (London: Zed Press, 1989) p 106.

${ }^{58}$ A Pollis and P Schwab (eds) Human Rights: Cultural and Ideological Perspectives (New York: Praeger Publishers Inc, 1980) p 4. Cited in S Poulter Ethnicity, Law and Human Rights (Oxford: Clarenden, 1990) p 109.

${ }^{59}$ Rule 41 Requests for priority pursuant to Rule 41 of the Rules of Court of the European Court of Human Rights.

${ }^{60}$ Article $36 \S 2$ of the Convention and Rule $44 \S 2$.
} 
Human Rights Advocacy Centre, Human Rights Watch, the International Commission of Jurists, the International Federation for Human Rights, JUSTICE, Liberty and REDRESS (otherwise referred to as "the group of interveners”). On June 30th 2009, the applicants case was heard before L. Garlicki, President, and Judges Sir Nicolas Bratza, G. Bonello, L. Mijovic; J. Sikuta, M. Poalelungi and N. Vucinic. ${ }^{61}$ On February $2^{\text {nd }} 2010$, having deliberated in private, the Court delivered its judgement. The judges took as their starting point (Protocol no 13), ${ }^{62}$ which states that convicted persons have a right not to be subjected to the death penalty and they pointed out that this right enshrines one of the basic values of democratic societies. They went on to say that the principles underlying the Convention cannot be interpreted and applied in a vacuum, therein very much embracing a "living instrument" approach to the Convention. ${ }^{63}$ In taking at the centre a fundamental objection to the death penalty they held, "it is not open to a Contracting State to enter into an agreement with another State which conflicts with its obligations under the Convention." ${ }^{64}$ And, therefore took the view that any agreement to transfer the men, with its attendant consequences for the men, would conflict with convention obligations. They then went on to say that such a principle "carries all the more force in the present case given the absolute and fundamental nature of the right not to be subjected to the death penalty and the grave and irreversible harm risked by the applicants." 65

On the question of the transfer of the men into Iraqi custody the ECtHR said this:

"The majority of the Chamber have found the Government's noncompliance with the Rule 39 indication to be unjustified on two principal grounds. It is said that there was no 'objective impediment' to compliance with the interim measures since the absence on 31 December 2008 of any available course of action consistent with respect for Iraqi sovereignty other than the transfer of the applicants was of the respondent State's own making. Secondly, it is said that the Government have not satisfied the Court that they took all reasonable steps, or indeed any steps, to seek to comply with the Rule 39 indication, not having informed the Court of any attempt to explain the situation to the Iraqi authorities or to reach a temporary solution

\footnotetext{
${ }^{61}$ Fourth Section Case of Al-Saadoon and Mufdhi v The United Kingdom (Application no 61498/08 Judgement 2 March 2010.

62 Ibid para [118].

${ }^{63}$ Ibid para [126].

${ }^{64}$ Ibid para [138].

65 Ibid.
} 
which would have safeguarded the applicants' rights until the Court had completed its examination.”66

In approaching this question the ECtHR considered the obligations of the ECHR as prospective and forward looking and not fixed in one moment in time or place, very much looking to the end of the justicial process. They said this: "the Court considers that the respondent State was under a paramount obligation to ensure that the arrest and detention did not end in a manner which would breach the applicants' rights under Articles 2 and 3 of the Convention and Article 1 of Protocol No. 13.”"

The ECtHR concluded:

"[143] In summary, therefore, the Court considers that, in the absence of any such binding assurance, the referral of the applicants' cases to the Iraqi courts and their physical transfer to the custody of the Iraqi authorities failed to take proper account of the United Kingdom's obligations under Articles 2 and 3 of the Convention and Article 1 of Protocol No. 13 since, throughout the period in question, there were substantial grounds for believing that the applicants would face a real risk of being sentenced to death and executed.[144] The outcome of the applicants' case before the IHT is currently uncertain. While the applicants remain at real risk of execution since their case has been remitted for reinvestigation, it cannot at the present time be predicted whether or not they will be retried on charges carrying the death penalty, convicted, sentenced to death and executed. Whatever the eventual result, however, it is the case that through the actions and inaction of the United Kingdom authorities the applicants have been subjected, since at least May 2006, to the fear of execution by the Iraqi authorities. The Court has held above that causing the applicants psychological suffering of this nature and degree constituted inhuman treatment. It follows that there has been a violation of Article 3 of the Convention.”... [171]. In the present case, the Court has found that through the actions and inaction of the United Kingdom authorities the applicants have been subjected to mental suffering caused by the fear of execution amounting to inhuman treatment within the meaning of Article 3 . While the outcome of the proceedings before the IHT remains uncertain, that suffering continues. For the Court, compliance with their obligations under Article 3 of the Convention requires the Government to seek to put an end to the applicants' suffering as soon

\footnotetext{
${ }^{66}$ Ibid: Partly dissenting opinion of Judge Bratza at para [13], although he said that he was not convinced by either of these two arguments at para [14].

${ }^{67}$ Ibid para [140].
} 
as possible, by taking all possible steps to obtain an assurance from the Iraqi authorities that they will not be subjected to the death penalty.”68

Altiparmak in 2004, in his critique of Bankovic has said, "The Iraqi war might require the ECrtHR to revisit this 'jurisdiction' definition" that "there should not be a shadow of doubt that POWs and civilians under British custody in Iraq fall within the jurisdiction of the United Kingdom" and "The ECtHR will have to redefine 'jurisdiction' if it receives an application from someone detained by British forces." ${ }^{69}$ The question is has it done so? The war on Iraq has indeed provided the ECtHR with the opportunity to revise its position on the application of the ECHR in military invasions. What did the ECtHR in Al-Saadoon have to say on jurisdiction? Somewhat surprisingly perhaps, the Court said nothing new on jurisdiction in fact it completely sidestepped the issue focusing exclusively on the ECHR obligations. In fact the ECtHR, has, in the words of Miller, ${ }^{70}$ "failed clearly to articulate when and why signatory states' extraterritorial actions can be brought within the jurisdiction of the European Convention.” The Court said:

"[155] This was, indeed, an exceptional case. If it was correct that the relevant acts fell within the jurisdiction of the United Kingdom, the case was by definition 'exceptional' in terms of the extraterritorial application of the Convention (see Banković, cited above, para 74). Further, the exceptional nature of the case derived specifically from the fact that the United Kingdom was acting or being required to act outside its own territory....[162] As stated above, the Court's approach in interpreting the Convention must be guided by the fact that its object and purpose as an instrument for the protection of individual human beings requires that its provisions be interpreted and applied so as to make its safeguards practical and effective."

Judge Bratza, in dissent, however did have something to say on the jurisdiction question and adopted a mechanistic approach to jurisdiction which followed in the the spirit of the British courts. He said: "While I in no way question these general principles laid down in the Court's case-law, I am not persuaded that they have any direct application to the special circumstances of the present case, where the two applicants were held by a

\footnotetext{
${ }^{68}$ Ibid para [143][144][171].

${ }^{69}$ See Altiparmak above n 34.

70 S Miller "Revisiting Extraterritorial Jurisdiction: A Territorial Justification for Extraterritorial Jurisdiction under the European Convention” European Journal of International Law 2010204 1223-1246.
} 
contingent of a multinational force on foreign sovereign territory, whose mandate to remain on that territory had expired and who had no continuing power or authority to detain or remove from the territory nationals of the foreign sovereign State concerned. It is these considerations which have led me to dissent from the majority of the Chamber in their finding that there have also been violations of Articles 13 and 34 of the Convention.”71

\section{WASHING OUR HANDS OF JURISDICTION}

The plight of Al-Saadoon and Mufdhi seemed of limited interest (at least at the time of writing) to the world's press either on the jurisdiction point or on the human rights point. The Independent newspaper in the English language press and sections of the Arabic press ${ }^{72}$ were however concerned with the long term detention of these men, the conditions of their detention, the potential abuse of their human rights, and the wider question of jurisdiction in the modern post-colonial ${ }^{73}$ age. It has been an erstwhile principle of law that everyone has the right to representation and the protection of the law, a right enshrined in Article 6 of the Convention. And in this regard, it is of significance that a formidable group of human rights lawyers and activists joined this case as interveners, because of the fundamental issues and rule of law upon which this case turned. However, the applicant's right to legal representation out of UK legal aid funds was vociferously challenged. ${ }^{74}$ But, it is to be remembered, as Henry Brougham put it:

"An advocate, by the sacred duty which he owes his client, knows in the discharge of that office but one person in the world, that client and none other. To save that client by all expedient means - to protect that client at all hazards and cost to all others, including himself, is the highest and most unquestioned of his duties; and he must not regard the alarm, the suffering, the torment, the destruction which he may bring upon any other. He must go on, reckless of the consequences...

\footnotetext{
${ }^{71}$ See above n 61. Partly dissenting opinion of Judge Bratza at para [9].

${ }^{72}$ Website of Ismail Alwan al Tamimi.

${ }^{73}$ I use this term not to suggest that colonialism is over but that we have entered a new colonialist era.

${ }^{74}$ Patrick Mercer, MP said: "It seems totally wrong to me that these men are being given legal aid. Would we have given legal aid to Nazis who committed war crimes in the Second World War - of course not - this is arrant nonsense" S Rayment, and B Leach The Telegraph, November $15^{\text {th }} 2008$.
} 
even if his fate it should unhappily be, to involve his country in confusion for his client's protection." 75

The fundamental question at stake was whether these men were entitled to the protection of the ECHR, especially, the right if convicted not to be executed, and whilst in detention to be free from inhuman and degrading treatment, and to receive a fair trial.

Dancing on the head of the pin of "jurisdiction" allowed both the court of first instance and the Court of Appeal, albeit with troubled minds, to wash their hands of the protection of these two men, by concluding that they fell outside the jurisdiction of the ECHR, and were therefore simply not our concern. In addition, applying an organic notion of territory allowed a retreat into a conservative model of "natural territory" which disregarded and stripped bare the complexity of the context in which this case was framed and fixed. This reification excluded the reality and context of the occupation and invasion by a foreign power. Such invasions are becoming an increasing tendency in the new colonialist era. In my view it is somewhat of a conundrum to treat jurisdiction in its ordinary meaning when it is being realised in extraordinary circumstances.

Such arguments were further aided by a rigid notion of what indeed was the relevant time, sine the time taken as the relevant time secured the negation of their right to protection. The British courts took the recent time and the time at which these men were transferred, 2008, as the relevant point. Their detention in a previous time frame, prior to 2008, and any obligations to the protection of the human rights of the two men whilst held in British custody, were excluded. This produced a somewhat illogical and piecemeal outcome which, in effect, placed the men beyond humanity's reach.

Principles of justice and humanity, the foundation stones of law and one of the declared reasons for the British government's invasion, were abandoned, through being subordinated to a fixed model of territory and relevant time, thereby ensuring an inevitable outcome. The Divisional Court stated that their decision left them "seriously troubled" because if convicted the men would face execution, whilst the Court of Appeal found any extension of the ECHR to Southern Iraq "manifestly absurd". Stripped of context and hermeneutically sealed off from what was, in fact, happening all around the court in this case began to resemble what Geoffrey Robertson has called "slot-machine jurisprudence". ${ }^{76}$

\footnotetext{
75 Monroe H Freedman Hofstra Law Review 2006344 Summer. See also In re Griffiths, 413 US 717, 724 n 14 (1973) (citation omitted). See also Cammer v United States, 359 US 399, 405 (1956), in which it was held that lawyers are more than just officers of the court "within the conventional meaning of that term".

${ }^{76}$ G Robertson The Justice Game (London: Chatto and Windus, 1998) p x.
} 


\section{THE DIFFERENCE MADE BY TELEOLOGICAL INTERPRETATION}

By stark contrast, the ECtHR approached the case from a very different vantage point and brought justice and a moral code into sight, translating these overarching principles into legal judgement. As Altiparmak writes, "the 'object and purpose' of the ECHR has been a crucial factor in the interpretation of the Strasbourg organs." ${ }^{\text {"77 }}$ The court was faced with a choice on the one hand of treating jurisdiction in the ordinary sense but denying the reality in which the men found themselves or indeed anyone might find themselves in Iraq under occupation, or on the treating jurisdiction in a way that took into account the reality of the circumstances and thereby honoured the universal aspirations of the Convention.

The ECtHR ostensibly started out from a natural law position à la Hobbes, not of territory but of the commitment and quest for a just and responsible law. A position which echoes the sentiments of Lord Acton, "Opinions alter, manners change, creeds rise and fall, but the moral law is written on the tablets of eternity." ${ }^{78}$ They approached the case with a mindset of justice. As Douzinas and Warrington, when writing on the essence of a just and responsible decision, state - such a decision "must both conserve and destroy, or suspend, the law enough to reinvent it and rejustify it in each case. Each case requires unique interpretation which no rule can guarantee absolutely. But, at the same time, there is no just decision if the judge does not refer to law or rule... This is the reason that we cannot say that a judgment is just. A decision....Cannot be declared just because justice is the dislocation of the said of law by the - unrepresentable-saying of ethics." ${ }^{79}$ Indeed, Lord Denning himself said, "I must do justice, whatever the law may be." 80

The ECtHR is indeed a living instrument and the need for it to be interpreted in the light of contemporary circumstances and context is rooted and reflected in its case law. As Altiparmak points out that this principle is derived from the nature of the ECHR. ${ }^{81}$ Effective protection (effet utile) lies at its heart requiring application of the provisions to ensure its safeguards are practical and effective.

\footnotetext{
${ }^{77}$ See Altiparmak above n 34.

${ }^{78}$ Cited in J Glover Humanity: a Moral History of the Twentieth Century (London: Pimlico, 2001) p 1.

${ }^{79}$ Cited in A Sarat (ed) Law, Violence and the Possibility of Justice (Princeton: Princeton University Press, 2002) p 7-8.

${ }^{80} \mathrm{G}$ Robertson The Justice Game (London: Chatto and Windus, 1998) p x.

81 R. Bernhardt “Thoughts on the Interpretation of Human Rights Treaties" in F Matscher \& H Petzold (eds) Protecting Human Rights: The European Dimension (Studies in Honour of Gérard J. Wiarda), (1988) 5 at 68-71.
} 
The vision and reach of the ECHR in ensuring effectiveness is also prospective or promissory - a performative utterance. $^{82}$ As Paul de Mann when writing about laws in general terms, "[they] are future-orientated and prospective; their illocutionary mode is that of the promise. On the other hand, every promise assumes a date on which the promise is made and without which it would have no validity; laws are promissory notes in which the present of the promise is always a past with regard to its realization." 83 It is in this sense that the ECHR is promissory: it promises to protect and secure fundamental human rights, and arguably does so from the moment a person falls within its reach right up until the end or conclusion of the judicial/justicial process. In this regard, once arrested and under British jurisdiction, both men were guaranteed henceforth, in both the present and the future, human rights protection. It was therefore this promissory role of the ECHR that the ECtHR implicitly relied upon, that is, to ensure the protection of Al-Saadoon and Mufdhi until the end or conclusion of that process, notwithstanding the fact that in 2008 the British forces were no longer in control and an Iraqi government was in situ. The teleological perspective applied by the ECtHR enabled new possibilities. It is worth reflecting on the construct of "time" in the writings of Avital Ronell who writes, "Justice can no longer permit itself to be merely backward looking or bound in servility to sclerotic models and their modifications (their "future"). A justice of the future would have to show the will to rupture...". ${ }^{84}$

And what of the judges? By disclosing two faces of law and two different approaches, one legally mechanistic, narrow, and one morally purposive and effective, the British courts and the ECtHR have demonstrated the inherent tensions within the law, between on the one hand its logic and its rules, and on the other hand its justice, played out in a context between international law and the ECHR principles. In theorising this dichotomy Robert Cover argues, "Because of the violence they command, judges characteristically do not create law, but kill it. Theirs is the jurispathic office...Among warring sects, each of which wraps itself in the mantle of a law of its own, they assert a regulative function that permits a life of law rather than violence." ${ }^{85}$ The British courts effectively asserted this regulatory function killed human rights

\footnotetext{
${ }^{82}$ See J Austin Philosophical Papers (Clarendon:Oxford 1960). J Austin How to do things with Words (Cambridge: Harvard, 1975).

${ }^{83}$ Paul de Mann Allegories of Reading: Fugural Language in Rousseau, Nietzsche, Rilke, and Proust (New Haven: Yale University Press, 1979) p 273.

84 A Ronell Wars: Literature Addiction Mania (Lincoln: University of Nebraska Press, 1992) p 21.

${ }^{85}$ A Sarat (ed) Law, Violence and the Possibility of Justice (Princeton: Princeton University Press, 2002). See also R M Cover “The Supreme Court: A Foreword”1983 97.4 Harvard Law Review p 53.
} 
law by privileging international law and its vision of territory above the potential universal reach of human rights. Cover calls upon judges to be less "jurispathic" and to "invite new worlds." ${ }^{86}$ The ECtHR judges clearly see the world through the language and concepts of the lens of the ECHR, inviting new worlds, and are driven by the will to rupture old ways of thinking with purposive and universalist aspirations.

Reading the judgement of the ECtHR in Al-Saadoon and Mufdhi we are also reminded of Drucilla Cornell's call to re-envision the good ${ }^{87}$ and her concern with the Law of Law. Cornell challenges the indifference of the law, an indifference which is produced and allowed by law, and perhaps, characterises somewhat the law as applied by the British courts in this case albeit that the Court of Appeal did say that it was "seriously troubled" by the outcome of their judgement. The consequence of the decision of the British courts provides an example of what Sarat calls "law's violence", unlike the ECtHR who in re-imagining and reconfiguring legal thought, principles, justice and the construct of time, and overriding the fixity of territory produced a protective outcome.

However, whilst the ECtHR held that Al-Saadoon and Mufdhi were indeed eligible to protection under the ECHR they, like the British courts, remained mute about the wider political context in which the men were detained. The two men, after all, were detained in Basra by the British military ${ }^{88}$ without trial for several years "for imperative reasons of security" and it was not until the last moment that it was decided that they were allegedly involved in these murders and therefore treated as criminal detainees. ${ }^{89}$ The conditions of their detention by the British military were as Mazin Younis of the Iraqi League, describes “...a mini-Guantanamo in southern Iraq, outside the boundaries of both Iraqi and British legal jurisdiction." 90 The two men were kept in solitary confinement where they alleged they were subjected to deliberate sleep deprivation, extreme heat, arbitrary body searches and physical abuse. ${ }^{91}$ Then, when the British authorities made it clear that they were going to simply disregard the Strasbourg injunctive ruling they were turned over to the Iraqi authorities. The

${ }^{86}$ A Sarat (ed) Law, Violence and the Possibility of Justice (Princeton: Princeton University Press, 2002) p 53.

${ }^{87}$ D Cornell "From the Lighthouse: The Promise of Redemption and the Possibility of Legal Interpretation”, 11 Cardozo Law Review 1687, 1709 (1990).

${ }^{88}$ Morning Star March $3^{\text {rd }} 2010$.

${ }^{89}$ The Independent September $11^{\text {th }} 2009$.

${ }^{90}$ The Independent September $11^{\text {th }} 2009$.

${ }^{91}$ Morning Star, March $3^{\text {rd }} 2010$. 
Courts, in the main part, avoided the factual realities of the experience of the men affected, and the consequences of any judgement. ${ }^{92}$

\section{THE FATE OF THE JURISDICTION QUESTION AND THE MEN}

As Shiner somewhat ironically remarks, "We went into Iraq on the basis that we would stand for the rule of law." "T3 The ECtHR decision in this case still leaves the question of territoriality unanswered. The two men currently remain in custody, in Rusafa 1 prison ${ }^{94}$ in Bahgdad. On $12^{\text {th }}$ January 2010 their case was been sent back by the Court of Cassation to the investigative chamber for a renewed investigation. Since then their lawyers have had no further information. With regard to the IHT their lawyers have been informed that it was decided by the Chief Trial Judge that the death penalty is no longer

92 This was not true in Al-Skeini and the House of Lords did albeit briefly recognise the suffering of Iraqi civilians. Lord Carswell [93] "My Lords, it is a sad but inescapable consequence of armed conflict that lives will be lost. Unhappily, some of the persons killed will be peaceable civilians caught in cross-fire. Others will have been shot by members of the armed forces involved, and the extent of the justification for shooting them which may be advanced will vary enormously with the circumstances. One of the appeals before the House concerned such an innocent civilian, and it cannot even be determined on the evidence presently available which group fired the shot which killed her. In four of the appeals the victims were shot by members of the British armed forces. As is very commonly the case in such situations, the versions of the facts retailed by witnesses differ markedly. The soldiers maintain that they were or reasonably thought themselves to be under attack, and so were within the rules of engagement. Civilian witnesses aver, however, that the victims were harmless and uninvolved citizens and that the shootings were unjustified. The sixth case is wholly different: Mr Baha Mousa died as a result of appalling maltreatment in a prison occupied and run by British military personnel. His treatment cannot for a moment be defended, but due to a regrettable paucity of evidence it has not proved possible to bring to justice those responsible for his death." 93 Law Society Gazette (2009) 14 June 2009 "Interview - Phil Shiner: Fighting the good fight”.

94 Sam Dagher, in A report that details torture at Rusafa - April 27, 2010,states, “...at least 505 cases of torture were documented in Iraqi prisons in 2009, according to a report released by the state department in March.” see http://www.state.gov/g/drl/rls/hrrpt/2009/nea/136069.htm See also Human Rights Watch http://www.hrw.org/en/news/2010/04/27/iraq-detainees-describe-torture-secret-jail "Detainees in a secret Baghdad detention facility were hung upside-down, deprived of air, kicked, whipped, beaten, given electric shocks, and sodomized, Human Rights Watch said today. Iraq should thoroughly investigate and prosecute all government and security officials responsible" 
an available sentence with the result that the charges were amended on July $29^{\text {th }} 2009$ and according to the Iraq Government "the death penalty is not an appropriate penalty for those charges." ${ }^{95}$

Meanwhile the territoriality question has also been considered in the context of British troops serving in Iraq. ${ }^{96}$ In $R$ (Smith $\left.v M o D\right){ }^{97}$ following the death of Private Jason Smith on August $13^{\text {th }} 2003$ from hyperthermiaheatstroke while serving in Iraq as a private soldier with the Territorial Army, the Supreme Court considered to what extent British soldiers serving in Iraq are protected by the European Convention on Human Rights and whether the inquest on Jason Smith should comply with Article 2 of the Convention. The Supreme Court, (Lord Phillips of Worth Matravers, President, Lord Hope of Craighead, Deputy President, Lord Rodger of Earlsferry, Lord Walker of Gestingthorpe, Baroness Hale of Richmond, Lord Brown of Eaton-under-Heywood, Lord Mance, Lord Collins of Mapesbury and Lord Kerr of Tonaghmore) by a majority of 6 to 3 (Lady Hale, Lord Mance and Lord Kerr dissenting in part) overturned a ruling of the Court of Appeal that held soldiers on active service outside the UK were indeed entitled to the protection of Convention rights, and found that they were not so protected (although found that an inquest should comply with Art 2). Considering the question of territoriality they concluded that they were bound by the decision of the House of Lords in Gentle, ${ }^{98}$ a case in which Gordon Gentle and Geoffrey Clarke were killed by a roadside bomb on June $28^{\text {th }} 2004$ - in 'friendly fire' so called - whilst serving in Iraq. Lord Brown concluded in Gentle:

[68] No member of the committee could fail to be moved by the plight of these appellants and others like them, the mothers of soldiers killed on active service in Iraq. Your Lordships naturally recognise too that the appellants' suffering is the greater because of their understandable concern that the invasion may not have been lawful in the first place. But however sympathetic your Lordships may be to the appellants' plea for a public inquiry to address and resolve the questions that so trouble them-most notably perhaps, whether the invasion was lawful under international law, how the Attorney General came to his opinion that it was, and whether perhaps the government was not in any event intent upon hostilities-your Lordships could only order such an inquiry if art 2 of the European Convention for the Protection of

\footnotetext{
${ }^{95}$ I am grateful to the legal team at PIL for providing me with the latest information on these two men.

${ }^{96} R$ (Gentle) v Prime Minister [2008] UKHL 20, [2008] 1 AC 1356.

${ }^{97}$ See above $n 4$.

${ }^{98}$ See above $\mathrm{n} 96$.
} 
Human Rights and Fundamental Freedoms 1950 (as set out in Sch 1 to the Human Rights Act 1998) requires it. [69] Each of your Lordships has reached the clear conclusion that the appellants' argument for an inquiry under art 2 must fail. That too was the conclusion reached by Collins $\mathrm{J}$ at first instance (who cannot be criticised for refusing permission to claim judicial review on the ground that it was unarguable) and by the Court of Appeal (who expressly granted the necessary permission not on the basis that the claim had any real prospect of success but rather because it thought there was compelling reason to hear it).[70] It is impossible to argue that art 2 of the convention was ever intended or is now apt to guarantee or police compliance by member states with art 2(4) of the Charter of the United Nations." 99

It is clear that the applicants in Gentle, were also concerned with wider questions including; the "manifest absurdity" of the foraging by the UK into other territories, on this occasion Iraq; trumped up global crime thriller tales of weapons of mass destruction; stockpiling in bunkers, and nuclear weapons that could destroy in 45 minutes. Notwithstanding the importance of these questions and concerns the fate of Al-Saadoon and Mufdhi is still undetermined even after the decision of the ECtHR and in Smith, (if appealed) the question of territory is still yet be concluded by the ECtHR. As Lord Hope said, "A decision that the extra-territorial jurisdiction should be extended that far in this case would be likely to have profound consequences for other member states.....and for the court itself. A decision of that kind is best left to Strasbourg." 100

${ }^{99}$ [2008] 3 All ER 1 at 26.

${ }^{100}$ Smith see above $\mathrm{n} 4$ at para 92. 